\title{
The Future of Taboos in Indigenous Ghanaian Morality
}

\author{
Ron Macaulay 1 \\ ${ }^{1}$ Global Theological Seminary, Accra Ghana.
}

\begin{abstract}
The problem that prompts this study is how cherished taboos that sustain communal life and instill morality in indigenous Ghanaian society are eroding fast before 'our very eyes.' This leads to the quest for some of the taboos, their places and the future in modern Ghanaian morality. To achieve this goal, the study blends ethical and theological methods as it adopts a qualitative technique in the analysis. It has been observed that taboos are assessed and therefore considered as irrational and superstitious ideas and sometimes retarding societal progress. Typical examples are to forbid working on a piece of land on a week-day which is seen to be retarding economic growth. Also, sex taboo rules that forbid sex in the bush, especially, on farmland and the bare floor are seen as primitive ideas. Parents are also afraid to advice their children to avoid marrying from families stigmatised by laziness, stealing, and cruelty. This study however recommends that taboos that are similar to Christian moral values such as marriage which is a sacred and social affair be encouraged. Furthermore, holistic moral conservation policies need to be implemented to enhance Ghanaian taboos as those that are evil are metamorphosed into acceptable forms of morality. This can only be achieved through intensive and effective teaching and learning. Finally, if moral education can be enforced at social gatherings, it will go a long way to inculcate or instill morality which could help generations unborn. This article fills the gap between taboo rules in indigenous Ghanaian morality and ethical principles in the Christian faith.
\end{abstract}

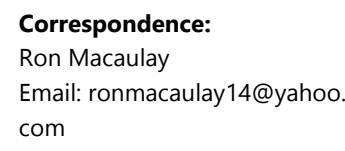

Publication History Received 18th August 2020, Accepted 24th September 2020, Published online 19th October 2020.

Keywords: Taboos, morality, modernisation, acculturation.

(c) 2020 The Author(s). Published and Maintained by Noyam Publishers.

This is an open access article under the CCBY license (http://creativecommons.org/licenses/by/4.0/).

\section{INTRODUCTION}

There is incontrovertible evidence that most human societies in Africa, which includes Ghana, have a set of taboos, which are code of conduct about what is good and bad, right and wrong. Naturally, the conduct of the individual must automatically have the well being of the entire community at heart. A breach of the code is regarded as a morally wrong act because it destroys the social order and peace of that society. Interestingly, it has been observed that certain traditional virtues are similar to biblical ones. Generally, some moral laws are common to the human race. Among the diversity of moral values are Ghanaian taboos. One important dimension of religion is morals. Morals in the indigenous Ghanaian perspective deal with the question of what is good or evil, which has to do with careful recognition of taboos. The full study of morality in all its vastness and dimensions belongs to the discipline known as moral philosophy, which studies the principles that govern human behaviour and takes time to examine their relationship to their environments. The topic, of course, is very ample and complex, and so this study only provides an introductory reflection.

In this study, though the writer is not oblivious to the fact that there are many taboos observed among Ghanaians, he touches on those that he thinks are necessary for this work. While the nature and place of Ghanaian taboos are highlighted, the future of taboo deals with whether taboo rules will still be observed, or will steadily diminish in Ghanaian society. Taboo is like an already existing text that requires interpretation. Yet it is not merely a reality to be explained, for humans not only receive taboos but actually make them and then hand them on to others. As a result, one may say that Ghanaian taboo consists of rules that are said to be implicit belief. It helps individuals to live morally right, having 
the community in mind since community life takes precedence over individualism. Notwithstanding the promotion of community life in the era of modernisation; the question is: is the observance of taboos still relevant? This provides a suitable background for an exploration of the nature of taboos in Ghana.

\section{The Nature of Taboos in Ghana}

In most indigenous Ghanaian societies, taboos are issues of concern. From a wider perspective, taboos are considered to be sacred, especially, in all the tribes of Africa. A taboo, according to Longman Dictionary, is a custom that says that "you must avoid a particular activity or subject, either because it is considered offensive or because your religion does not allow it." In a wider perspective, a taboo primarily serves the purpose of ritual protection or ritual hygiene. Ayegboyin and Jegede confirm the fact that taboo is embeddedded in the myths and religions of Africans and most African countries and communities of which Ghana is one. Taboos are numerous, they cover almost every aspect of African life and they are taken seriously. ${ }^{2}$

Outside Christianity, every human society has a set of ideas about what is good and bad, right and wrong. Also, in Ghanaian cultures, God is fundamental to belief systems. Thus, the moral life of the Ghanaian must point to the Supreme Being and following his will. God is acknowledged as the Final Guardian of the moral code and law and order. Again, the ancestors also have a keen interest in the law. ${ }^{3}$ This means that a taboo has some element of spiritual effect which has further connection to the Supreme Being who is God, and also an act that attracts the attention of the ancestors. In other words, committing a taboo is similar to committing a sin against the ancestors and God. In traditional thought, sin may be described as the breach of prohibitions imposed on a human being by his object of worship or the doing of anything that is displeasing to spirit powers with the result that the displeased spirit powers manifest themselves adversely in human affairs. ${ }^{4}$

\section{The Place of Taboos in Indigenous Ghanaian Morality}

This paper deliberates and ascertains what Ghanaians know, believe, and think about the foundations of morality. Taboos deal with the question of good and evil. In most societies, these are framed into ethical norms concerned with the regulation of human conduct. Naturally, the conduct of the individual must automatically have the wellbeing of the entire community at heart. Through taboos the conduct of the individuals are regulated. Any break of the taboos of a society is regarded as bad and punishable. The essence of taboo rule in Ghanaian ethics lies in a strong belief that the human being must mature morally by inculcating certain virtues and shunning others. Taboo rules of these natures are considered as more serious and to be strictly observed. ${ }^{5}$ Some of the positive virtues recommended are kindness, hospitality, hard work, keeping societal taboos, patience, chastity before marriage, faithfulness during marriage, honesty, mercy, generosity, truthfulness, justice, humility, among others. ${ }^{6}$ Traditional sources of moral values are enshrined in customs and traditions, religious beliefs, the sense of community solidarity, experience, common sense, conscience, proverbs, wise sayings, the relics of songs, and so forth.

According to Ansah, there are laws, regulations, customs, ritual observations, beliefs and taboos that govern the behaviour and life of the people that constitute a code of conduct preserved in oral tradition. Also, there is a body of codes which are rules of behaviour not put down on any paper. A breach of those codes is regarded as a moral wrong, a morally bad act because it destroys precisely the social order and peace which the code is meant to effect. ${ }^{7}$ Some of those moral wrongs or vices are: murder, abortion, stealing, falsehood, causing disunity, among many others are also a class of taboos.

Society also serves as a check on the moral conduct of its members, for it is believed that a society that does not do this may not only disintegrate, but come to corporate punishment from God, the gods, and the ancestors. Ostracism and public disgrace are also used to punish offenders. In some societies, when adultery is discovered it is severely dealt with. The guilty person may be whipped, stoned to death, made to pay compensation or parts of his body mutilated. However, this severe manner of punishing adultery and other sexual offences has been modified or relaxed in modern times, but not altogether. Fornication, incest, rape, seduction, homosexual relations, sleeping with a domestic animal, children watching the genitals of their parents; all constitute sexual offences in a given community. ${ }^{8}$

The traditional mediums through which code of conduct is imparted are both formal and informal. Among

\footnotetext{
Longman Dictionary of Contemporary English, Updated Edition, 2007.

Deji Ayegboyin and Charles Jegede, Divinities (2009), 1. In Molefi Asante and Mazama, Ama (eds.): Encyclopedia of African Religion. Sage, Thousand Oaks,

210-213, https://doi.org/10.4135/9781412964623.n139

Kofi Asare Opoku, West African Traditional Religion (Legon: FEP International Private Limited, 1977), 152 - 157.

Christian R. Gaba, Sin in African Traditional Religion (Accra: Presbyterian Press. The Ghana Bulletin of Theology. Vol. 4. No. 1. 1971), 22.

John K. Ansah, Taboos in Ghana: The Ethical Wisdom of our Fathers (Stayler Verlag, Wort Werk. Neitetal. 1988), 259.

John S. Mbiti, African Religion and Philosophy (Heineman Educational Books Inc. New Hampshire. 1989), 207.

Ansah, Taboos in Ghana: The Ethical Wisdom of our Fathers, 258.

Mbiti, African Religions and Philosophy, 144.
} 
some Ghanaian ethnic groups, especially the Akan, Krobo, and Ewe, normal occasions for moral instruction normally occur during puberty and other rites of passage, such as naming ceremonies, and when someone passes away. At child naming ceremonies, family members meet to perform the rites. Common example is what takes place among the GaAdangbe and Ewe, which some regard as a pagan religious function. Libations are poured as the religious aspect of the ceremony, after which words of advice and wisdom that are said to the baby are said in the belief that the elders can take responsibility on behalf of the baby. ${ }^{9}$ Also, advice is given to the couples that remind them of their marital responsibilities.

The informal code of conduct includes the domestic training from childhood. For instance, proverbs and wise sayings are one medium of such instructions on human conduct. What they do is to express the virtues cherished by the society which serve as prescription for action. Again, they often also portray judgement in times of moral lapses. The committing of sin in the Ghanaian society comes in many forms. One of the ways these sins are committed is the termination of premature pregnancy. It is unacceptable for a girl to become pregnant before her puberty rite is performed. This taboo law is to deter physically grown but immature girls from taking upon themselves the responsibility of motherhood for which they are not prepared. One of the purposes of not allowing girls to become pregnant before their puberty rites is to inculcate in young girls the virtue of chastity. ${ }^{10}$

Also, Ghanaian morality forbids causing harm to a relative, a kinsman, an in-law, a foreigner and a stranger, except when such a person is involved in an immoral act. When such is the case, they stay away from such an individual, and even at death their corpses are not dignified with a noble burial in a coffin or grave.

One instance is whenever there is a breach of any reasonable behaviour; there is the fear that either the community or the family may be affected, which most of the time does not affect the offender. One would agree that because of the fear of the effect, there should be the need to remove that sin, since sins are justified and considered divine prohibitions. This sometimes calls for rituals to be performed to remove the committed sin.

One direct remarkable moral observation in most of the towns in the southern part of Ghana is the ritual cleansing of a community. In many places, such a ritual cleansing is made an annual event. Members of the community get some palm fronds to sweep every corner of each house and the whole town. All the things swept in the exercise together with the palm fronds are used as brooms and are ceremonially burnt, which the people believe, carries away the uncleanness and unpleasantness from the community. ${ }^{11}$ Though it looks like religious performance, it is a way of teaching the people how to live a communal life and to make sure their community is clean. In this regard, avoidance of open defecation and prohibition of refuse dumping in water bodies are strictly observed.

There is another practice known as "Trokosi" or "Shrine slave." For instance, whenever there is a breach of the moral law by a male, there is the fear that either the community or the family may be affected. When this happens, it is the close relatives and very distant ones who may pay the price. ${ }^{12}$ The practice calls for virgin girls to be sent to the shrines of the gods to pay for crimes committed by one of their relatives. They become living sacrifices, protecting their families from the gods' wrath. Some stay at the shrines for a few years; others for life.

This practice serves the rural communities' need for justice and meets the material and sexual needs of the priests. But it is also considered a spiritual act. The girls are sent to the shrines by their own parents to appease for the sin committed to prevent sickness, misfortune or death that might befall the family members. As these female girls are encamped to render services inimical to their will, they are being deprived of their freedom. Most of them get married to the priests in charge of the shrines who do not care for the mother and the child. One of the priests, during an interview by a Non-governmental Organisation, indicated that "people who do not understand the system feel it is servitude, but it is a blessing because that girl who comes to the shrine will protect her family from harm." 13

The practice to enforce morality in indigenous Ghanaian society to deal with sins committed is, to some extent, a laudable moral rule which Ghanaians must embrace. However, the concern has to do with the method adopted to deal with the issue as a means of enforcing morality. Why should someone - a male - breach an interdiction while someone else, especially, an innocent virgin girl suffer and be humiliated for the consequences? Would that not rather encourage immorality on the part of males, because they are not punished to serve as a deterrent to others? This method of enforcing morality may be considered an abuse of human rights of innocent virgin girls. God spoke through Ezekiel that, "For every living soul belongs to me, the father as well as the son - both alike belong to me. The soul who sins is the one who will die" (Ezekiel 18: 4).

According to Kudadjie, though, it is a way of promoting moral values in these areas, nevertheless, "any action that ensures the wellbeing of the family, tribe, and community is praised as being right even where the act considered in itself

\footnotetext{
Joshua N. Kudadjie, Does Religion Determine Morality in African Societies: A Viewpoint (The Ghana Bulletin of Theology. 1973 ), 37.

0 Ansah, Taboos in Ghana: The Ethical Wisdom of our Fathers, 263-4.

Omosade Awolalu, 'Sin, and its Removal in African Traditional Religion' Journal of the American Academy of Religion. 44.2 . ( 1976) 272. https://doi.org/10.1093/jaarel/xliv.2.275

12 Christian R. Gaba, Sin in African Traditional Religion (The Ghana Bulletin of Theology. Vol. 4. No. 1. Printed in Ghana by Presbyterian Press. Accra. 1971 ), 27.

13 Veronique Mistiaen, Virgin wives of the fetish Gods - Ghana's trokosi tradition https://news.trust.org/item/20131003122159-3cmei/(2013).
} 
might be condemned." ${ }^{14}$ One would realise that this is a sort of humiliation, slavery, and maltreatment of innocent girls who need to be liberated.

Among certain tribes of the southern part of Ghana, insulting a woman's private part results in all adult married women in the community going on a sex strike. In certain places, all adult women go almost naked on the streets as they drag themselves on the ground pronouncing curses along. When it happens like this, the elders see to it that either the culprit is dealt with or the sin is removed by performing rituals of purification. It is believed that if that is not done, the gods and the ancestors may be angry, and in the cause punish the community by allowing explosive epidemics and unexpected deaths to befall the community members. This is because generally, Africans are much aware of evil in the world, and in various ways endeavouring to fight it. Again, many societies say categorically that God did not create what is evil, nor does He cause them any evil whatsoever. ${ }^{15}$

Another taboo rule, which is strongly observed among some ethnic groups in Ghana is that, one does not have to greet anyone when attending to "nature's call." The question is: what effect does it have on the person greeted? Greetings are words or gestures used politely to salute people on meeting them, or on arrival at a destination. Words of greetings vary according to time of day and occasions. They may be long or short depending on people with individual names mentioned as they seek to know the welfare of the family. Expressions are also varied to show various levels of intimacy, respect, and relationships. Careful observation of this taboo as a moral rule has a peculiar meaning if understood would enhance human dignity. To some degree, it may mean to prevent one from defecating in one's clothing which may be a disgrace, which has no moral effect on the person if greeted. This taboo can be taken as a hygienic moral rule, and the ethical measuring rod resides rather in the consequence. ${ }^{16}$ Simply put, if a person wants to spend the time to greet at all cost, he/she may in the process turn to disgrace him/herself. To be on the safer side is to avoid the greeting in order to attend to "nature's call." It simply means that one either chooses to greet or not. However, many seem to have understood the meaning the other way round, and took it to be an insult when greeted.

Looking at cohabitation as a sexual ethical phenomenon from an African perspective, Opoku establishes that Africans pride themselves in the moral principle of permissibility of sexual intercourse only within marriage; therefore, sex outside the marriage union, such as cohabitation is frowned upon by them. ${ }^{17}$ Hence, sex and marriage taboos are respected among Ghanaians because sex is considered to be sacred in all the tribes of Ghana. ${ }^{18}$ Also, it is forbidden for a man to cohabit with a woman, especially, on the bare ground. It is an unclean act and it desecrates the earth. A person who breaks such a taboo will have to undergo an elaborate ritual ceremony lest he is overtaken by disaster. ${ }^{19}$ From the traditional point of view, marriage is a social rather than an individual affair. It is a social contract in which the lineages of the contracting parties are greatly interested. Parents advice their children to avoid families stigmatised by laziness, marked for cruelty or among whom there prevails dreadful infectious diseases. Besides this law, the question is: why do many young men and women who are sexually active cohabit?

It is believed that modernisation and acculturation are the problems in most African countries. According to Encarta dictionary, acculturation is a change in the cultural behaviour and thinking of a person or group of people through contact with another culture. ${ }^{20}$ At various points of life, indigenous values clash with alien counterparts. ${ }^{21}$ This includes Ghana and other African countries as to how they quickly embrace other cultures, which seems to be a problem for African morality. It is apparent that African moralities with its taboos were effectively working in the African society. For example, fertility and compatibility were not tested before marriage. The questions are: What had been the problem with African morality and its taboos? What had informed the adolescents' decision to consider cohabitation? The response to these questions can still be directed to acculturation and the way sex is currently portrayed in the media as contributory factors to the problem of adolescents engaging in premature sexual activities. ${ }^{22}$

While acculturation has caused indigenous values to lose their meaning, it has also established that the way sex is portrayed in the media is a factor. Prominent are stereotypical sexual roles featuring women as sexual objects, whose value is based solely on their physical appearance, giving in to male pressure, and gambling that sex is a way to get a boyfriend..$^{23}$ Nevertheless, those who are properly married are respected in society.

Other taboos are forbidding having sex in the bush, especially, on a farm land and on the bare floor. The belief behind this prohibition is that a sexual act performed in this form is an abominable offence that brings disaster to the

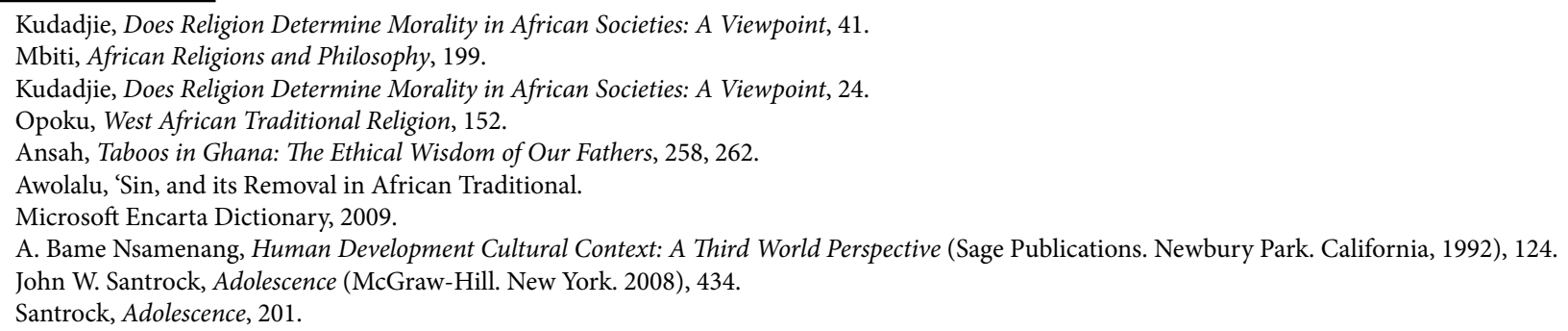


community in the form of famine. Since the forest and farm are abode of the gods, and the earth is a goddess. Sexual intercourse in this manner defiles the earth goddess and the habitat of the gods. The divinities punish by making the land infertile, and consequently, causing famine. ${ }^{24}$ However, one would notice that many of these taboos seem to be ineffective in contemporary Ghanaian society.

Another taboo is that, one cannot just dig a grave in order to bury a corpse without seeking permission from the elders. Traditionally, death is not considered an end to life, but the beginning of another life in the land of the dead. This requires various rites to separate the deceased from those who are still alive and to settle the deceased person in the world of the dead. When the mortal remains of the person is to be buried, rituals are performed after instruction is received from the diviner. Where the corpse is to be buried is also enquired by divination. This is the responsibility of the elders, because some corpse may be buried at designated cemeteries with peculiar rites. The main aim of such rituals is to uphold the moral norms of society in order to avoid pollution attributed to the death.

\section{The Future of Taboos in Indigenous Ghanaian Morality}

As Ghanaians, most of these taboos are associated with the deities. Currently, taboos are for the most part evaluated as irrational, superstitious or retarding progress by modern societies. Besides, there are even more extreme views about them. Taboos appear this way if they are judged in the context of modern life and the modern worldview. They seem to be nothing but absurd, superstitious and are often practised by societies living in conditions untouched by civilisation. Typical examples are to forbid working on a piece of land on a week-day, whistling at night or to forbid a cock crowing at night. Interestingly, the reason to forbid a cock to crow at night is not well known. One would notice that there are other birds and animals such as the black owl which hoot at night, and dogs that bark at night without breaking any taboo rule. Now, the question is: why is the cock alone subjected to this taboo rule? Maybe there is a mystical dimension to it which is not known by many. Notwithstanding, taboos in the form of rules and objects have shaped the ethical life of the African and their communities have drawn great strength from them and may continue to do so for generations to come. ${ }^{25}$ In order to present Ghanaian morality to any particular group of people properly, it is essential that one has adequate knowledge of taboos and some of the means to acquire that knowledge are through intensive teaching of moral laws in basic institutions as the curriculum is modified to meet the demand.

Absolutely fascinating, certain traditional virtues are similar to biblical ones. Generally, some moral laws are common to the human race. Thus one area of religion that people often compare is morals. Though morals are one dimension of religious life, similarities must not lead to the wrong generalisation that all religions are the same. Careful observation reveals that, though some of these taboos such as ostracism, mutilation, stoning to death, and so forth have perfectly worked in time of old, they may not be the same in these contemporary times. One popular culture is that some practitioners of African traditional religion change from their religion to Christianity. This is because humans are free to choose which religion to affiliate with, and what to pay allegiance to, which includes the moral rules that one has to obey. Within Ghanaian tradition, these are known as taboos. The fact that urbanisation is on the increase means, taboos seem to be dying out. Also, because of a lot of education, these taboos seem to be disappearing, or they are metamorphosing into social vices such as corruption and armed robbery.

In this contemporary world, modernisation seems to help any society to be well informed about how to behave morally right, and to be able to know the positive and negative consequences of any action that people take in their societies. It is also about doing or making things more modern. Surprisingly, while we are in a modern world, morality seems to be fading in our very eyes. Modernisation does not always mean humanity should throw away every bit of taboo rules. Some common examples are where defecating at open places and dumping of refuse in water bodies are prohibited. These types of taboos are to ensure cleanliness. Hence, inference can be drawn that, modernisation and taboo laws can work together to make every town and city clean.

On the one hand, it is suggested that in order to avoid more serious future socio-cultural change in societies, government should sensitively design and implement programmes to retain Ghanaian moral roots. This will go a long way to help gain control over the "modifying effects of alien influences." ${ }^{26}$ Again, gaining control and maintaining one's moral values, especially, Ghanaian morality is relevant and paramount over all else. Ghanaian morals and ethics are affected by external influences, which enable societies acculturate as a means of contacting other cultures, which eventually tend to modify their way of life by appreciating and adopting certain behavioural patterns. ${ }^{27}$ On the other hand, it is also suggested that "parents could serve as regulators of their adolescents' social contact with peers, friends, and adults." Also, parents should not be afraid to advice their children to avoid marrying from families stigmatised by laziness, stealing, cruelty or among whom there prevails dreadful diseases.

\footnotetext{
Ansah, Taboos in Ghana: The Ethical Wisdom of our Fathers, 262 -263.

Ansah, Taboos in Ghana: The Ethical Wisdom of our Fathers , 262.

Nsamenang, Human Development Cultural Context, 124.

Nsamenang, Human Development Cultural Context , 125.
} 
There is a clear cut that mothers are more likely than fathers to have a managerial role in parenting, especially, the female child. ${ }^{28}$ Both scholars may be right, because discarding one's virtues for no apparent reason is equal to trashing one's identity and dignity. Again, a nation that does not value its culture is like a nation without an identity. However, culture and its ethics are dynamic and must be allowed to transform evil structures. Thus, adopting "practices that would bring development to the people involved," as moral norms are considered, while discarding the bad ones. ${ }^{29}$ This means that if a society does not maintain a high level of moral integrity and work ethics in order to eschew corruption and armed robbery, it cannot realise any appreciable measure of social or economic development. ${ }^{30}$

\section{The Influence of Christianity over Taboos}

Christianity holds a moral sense of justice and truth, and the knowledge of the existence of God, good and evil. ${ }^{31}$ Interestingly, taboos are also about the gods, ancestors, good and evil. As taboos are important in Ghanaian morality, so are God's laws in Christianity written in the Bible.

The Bible is clear on religious and moral matters. It enjoins all that, "You shall have no other gods before me" as a religious matter (Exodus 20:3). The moral aspects are "Honour your father and your mother." "You shall not murder." "You shall not commit adultery." "You shall not steal." "You shall not bear false witness against your neighbour." "You shall not covet your neighbour's house; you shall not covet your neighbour's wife..." (Exodus 20: 12-17). All these laws of God are the seven of the Ten Commandments which enjoins all to comprehend the duty to God themselves and one another. The command forbids man from invading his neighbour's rights, taking his goods, house, wife, or field from him. Christ emphasises these laws in Mark 10: 19. The fact is that, "When God judges our choices; he is interested in our motives." The story of Joseph illustrates this point. When Joseph's brothers sold him into slavery, they did so with wicked motives. The single event of Joseph's imprisonment and enslavement involved two different parties with different and conflicting motivations: God and Joseph's brothers. God meant it for good, and Joseph's brothers meant it for evil (Genesis 50: 20). The decision of Joseph's brothers to sell Joseph was not spontaneous or neutral because they were jealous of their brother and this was their motivation for selling him. ${ }^{32}$

To determine what constitutes moral behaviour, one has to observe and reflect upon the social life of the people: their rituals, custom, practices, events and relationships. It is because God has made human beings spiritual and moral beings that religion, ethics, and godliness are fundamental to authentic humanness. To be able to live an acceptable moral life, God takes the initiative and comes to the soul of human beings with a transcendent moral claim or rightness. When a man recognises that claim, and voluntarily surrenders himself to it, he has come under the rule of God. ${ }^{33}$ The effectiveness of the rule of God is when Christians apply the words of the Bible, which can transform their moral life to live a life of chastity. In Christianity, godliness concerns what is morally good or right, which has to do with human beings in their responsibilities towards society, such as, civil and economic issues, suicide, abortion, the forms of permissible sexual relationship, the status of women, the right to property and what constitutes theft, the duty to tell the truth, the sanctity of life, among others.

Jesus emphasised that one cannot become morally good apart from having a genuine religious experience (John 4: 10-29). According to him, love for God is basic for one to have love for his neighbour (Mark 12:30-31). Zacchaeus had a religious experience when Jesus dined in his home, and he determined to correct the ills of robbery and deceit which had characterised his dealings with others (Luke 19: 8). When the rich young ruler asked Jesus what he should do to inherit everlasting life, Jesus responded by saying that he should go, sell all his goods, and distribute them to the poor (Matthew 19: 21). This requirement indicates that sincerity in religious moral motivation also implies concern for the conditions of others. Hence, Jesus taught that morality is a matter of inner being as well as external conduct.

Therefore, it is suggested that, holistic moral conservation policies be implemented to enhance Ghanaian taboos as those that are evil in nature are metamorphosed into an acceptable form of Ghanaian morality. Also, community cleansing which is similar to the modern type of "communal labour" should be encouraged without any superstitious idea attached to it.

\section{CONCLUSION}

It has been indicated copiously that, Ghanaian morality is socially acquired and passed on from one generation to another generation. As stated earlier, the common wellbeing of the community takes precedence over the rights of the

\footnotetext{
28 Santrock, Adolescence, 281.

29 Joshua K. Kudadjie, Rebecca Y. Ganusah and Adekunle Alalade, Religion Morality and West African Society (West African Association of Theological Institutions, 2002), 31.

30 Kudadjie, Ganusah and Alalade, Religion Morality and West African Society, 37.

31 John 0. Umoh, Elements of Sociology of Religion (Ikot Ekpene: Iwoh Publishers, 2005), 68.

32 Isaac Boaheng, "Divine Sovereignty, Human Responsibility and God's Salvific Plan: An African Perspective." E-Journal of Religious and Theological Studies 5, no.3 (2019): 84-93. https://doi.org/10.32051/09301909.

33 James Gills, Biblical Ethics and Contemporary Issues (Makati City: Carid Baptist Publications, 1994$), 95$.
} 
individual in every decision and the steps that one takes. Also vividly discussed in this work is how it would do much good to contemporary society if communities could be reminded of how Christianity influenced Ghanaian morality. Jesus emphasised that one cannot become morally good apart from having a genuine religious experience. Hence, he taught that morality is a matter of inner being as well as external conduct. Though taboos are important features in indigenous Ghanaian morality, ostracism, mutilation, stoning to death, among many others need to be avoided. But taboos that are similar to Christian moral values need to be considered and strictly observed. Also, to present Ghanaian morality to any particular group of people properly, one must have adequate knowledge of taboo laws. Thus, some of the means to acquire that knowledge are through intensive teaching of moral laws in the basic institutions as the curriculum is modified to meet the demand. Also, taboos that are similar to Christian moral values need to be considered and strictly observed. This can only be achieved through intensive and effective teaching and learning. Finally, if moral education can be enforced at social gatherings, it will go a long way to inculcate or instil morality which could help generations unborn.

\section{ABOUT AUTHOR}

Ron Macaulay holds a Master of Philosophy in Study of Religions Degree from the University of Ghana, Legon. He is an Ordained Minister of the Global Evangelical Church and a Lecturer at Global Theological Seminary, Ghana.

\section{BIBLIOGRAPHY}

Ansah, John K. Taboos in Ghana: The Ethical Wisdom of our Fathers. Stayler Verlag, Wort Werk. Neitetal, 1988.

Ayegboyin, Deji and Charles Jegede. Divinities In: Asante, Molefi - Mazama, Ama (eds.): Encyclopedia of African Religion. Sage, Thousand Oaks, (2009): 210-213, https://doi.org/10.4135/9781412964623.n139

Awolalu, Omosade J. 'Sin, and its Removal in African Traditional Religion' Source: Journal of the American Academy of Religion. Vol. 44. No. 2 (June 1976), 281. https://doi.org/10.1093/jaarel/xliv.2.275

Boaheng, Isaac. "Divine Sovereignty, Human Responsibility and God's Salvific Plan: An African Perspective." E-Journal of Religious and Theological Studies 5, no.3 (2019): 84-93. https://doi.org/10.32051/09301909

Definition of Determinism. Chicago: Encyclopaedia Britannica Ultimate Reference Suite, 2010.

Gaba, Christian R. Sin in African Traditional Religion. The Ghana Bulletin of Theology. Vol. 4. No. 1. Printed in Ghana by Presbyterian Press. Accra, 1971.

Gills, James. Biblical Ethics and Contemporary Issues. Makati City: Carid Baptist Publications, 1994.

Kudadjie, Joshua N. Does Religion Determine Morality in African Societies: A Viewpoint. The Ghana Bulletin of Theology, 1973.

Kudadjie, Joshua N., Rebecca Y. Ganusah and Adekunle Alalade, Religion Morality and West African Society. West African Association of Theological Institutions, 2002.

Mbiti, John S. African Religions and Philosophy. Heineman Educational Books Inc. New Hampshire, 1989.

Mistiaen, Veronique. Virgin wives of the fetish Gods - Ghana's trokosi tradition (2013). https://news.trust.org/item/20131003122159-3cmei/

Nsamenang, Bame A. Human Development Cultural Context: A Third World Perspective. Sage Publications. Newbury Park. California, 1992.

Opoku, Kofi Asare. West African Traditional Religion. FEP International Private Limited. Legon, 1977.

Santrock, John W. Adolescence. McGraw-Hill. New York, 2008.

Umoh, John 0. Elements of Sociology of Religion. Ikot Ekpene: Iwoh Publishers, 2005. 